\title{
The effects of religious education on prodemocratic positions in the face of the right-wing populism in Poland:Theoretical analysis and clues for educational practices
}

\author{
Mariusz Chrostowski ${ }^{1}$ D
}

Accepted: 3 February 2022 / Published online: 10 February 2022

(c) The Author(s) 2022

\begin{abstract}
The Right-wing populism in Poland faces multiple challenges with respect to Religious Education. This is a complex issue, given it is not only about school education supporting pro-democratic positions in the modern generation of students, but also the fact that today's populists have participated in long-term and complex educational processes of a similar nature. In this sense, the aim of this article is to seek an answer to the question of how Religious Education in Poland-with all of its theoretical and cognitive background rooted in the Christian vision of God and human and the world-can contribute to the elimination of the alliance of the right-wing populist perspectives from the dominant religion of the nation. The article will explain how practical educational opportunities will help students to understand the political strategy of populists, decipher their presentations and approaches, and so shape a positive attitude towards democracy as a desired ideological system within government and social life.
\end{abstract}

Keywords Religious education $\cdot$ Populism $\cdot$ Democracy $\cdot$ Poland

\section{Introduction}

"Today's Poland as a Bastion of Conservative Populism" - is an intriguing title of one of the reader's letters published in the "Inquiries Journal" (Myjak, 2020). Nevertheless, this is a statement that realistically depicts the Polish social situation since the presidential and parliamentary elections in 2015, when the right-wing party of Law and Justice (PiS) decided to conduct the so-called "elite replacement" (Hanley \& Dawson, 2017; Tworzecki, 2019; Tworzecki \& Markowski, 2017). An important tool in the hands of the right-wing populists ${ }^{1}$ in Poland was to achieve a goal of "elite replacement", which has become the Catholic religion (Stępińska et al., 2017). Approximately 90 per cent of Poles

\footnotetext{
1 Currently, in Poland, the problem of left-wing populism is a marginal phenomenon. The state of affairs is supported by the specificity of Polish politics and society. Firstly, it is about the different nature of the Polish left and right wing from similar groups in the West. In countries not burdened with communism, the left is the guardian of socialist ideology, which prefers to equalize social opportunities, egalitarianism and

Mariusz Chrostowski

m-chrostowski@wp.pl

1 Philosophisch-Pädagogische Fakultät, Katholische Universität Eichstätt-Ingolstadt, Bayern, Germany
} 
identify themselves as Catholic (Cooperman et al., 2017). The right-wing populists create a strong affiliation with Catholicism at the ideological level, e.g. conservative moral order, defense of the patriarchal family, ethnocentric focus on the Polish nation (Pankowski, 2010; Stępińska et al., 2017). Religious knowledge, images and symbols are becoming an element of the ideological struggle of populists around such issues as the recognition of LGBT rights or the immigration crisis in Europe (Herbert, 2019; Turska-Kawa \& Wojtasik, 2020).

This political, social and religious context also creates the framework for the functioning of the Polish education system. It situates the schools and religious education (religion lessons) against difficult tasks of shaping competent citizens, who are, and will be critical of populist positions. Therefore, this paper seeks to find an answer to the question of how religious education in Poland-with all its theoretical and cognitive background rooted in the Christian vision of God, human and the world - can contribute to the elimination of the "unholy alliance" of the right-wing populist from the religion (Chrostowski, 2021b; Steinmetz-Jenkins \& Jäger, 2019), and how to strengthen prodemocratic positions ${ }^{2}$ in more practical ways among students. In this regard, Religious Education is an important social phenomenon in counteracting populism, given that about 88 per cent of all students attended religion classes in 2019 (ISKK, 2020). Moreover, the curriculum for teaching religion in Poland from 2010 to 2018 (Polish Bishops' Conference, ) did not directly support the development of any populism-neither right-wing nor the left-wing. However, the "Toledo Guiding Principles" (OSCE, 2007) were respected in Poland. The Guiding Principles guarantee that the legal framework, content and tasks of Religious Education in this country, respect the values of a democratic society in accordance with the basic content of the Christian doctrine (Obrycka \& Dąbrowski, 2018).

\section{Religious Education in the function of democratization}

The process of democratization, the transition from an undemocratic system to a democratic one, involves a whole sequence of transformations that results from and follows one another in the social reality (Whitehead, 2002). In Poland during the 1980s, as in no other region of Central and Eastern Europe, there was a strong level of political mobilization, the core of which was the trade union "Solidarity" ("Solidarność"). As a result of these events, in 1989, a dialogue with representatives of the communist authorities was initiated and a political revolution was carried out. An important aspect in this regard was the opposition by the Church which had great authority among politicians and citizens (Antoszewski,

\footnotetext{
Footnote 1 (continued)

protect the poor against exploitation. In the social sphere, the right is associated with the conservative ideology, which oscillates around the defense of traditional and religious values and the rich. On the other hand, in the economic sphere, the right focuses on the idea of the free market. In Poland, right-wing and left-wing views have mixed and, in many cases, overlap. Besides, the second specificity of the development of rightwing populism in Poland is the crisis of the liberal center party. Due to the numerous failures of liberals and the negative social perception of reforms, populism now manifests itself in the form of intimidating society with the label of "progressive liberal" (Przyłęcki, 2012a, 2012b).

2 Pro-democracy positions are understood as attitudes of students that favor and support democracy. It is therefore about internal compliance with the democratic organization of social life, which consists in respecting the freedoms and rights of other people and the possibility of all people participating in the decision-making process (Munck, 2014).
} 
2012; Dudek, 2004). Furthermore, the high level of religiosity of Poles and their positive attitude towards the Church in $1990,{ }^{3}$ enabled the return of religious education to Polish schools after thirty years of exile during the Polish People's Republic (1952-1989) (Janiga \& Mezglewski, 2001). From the time of the exile, religion lessons in Poland became an object aimed at preparing students to understand the changing influence of religion on societies, as well as various cultural and social changes that also supported the ongoing process of democratization of the Polish state (Chrostowski, 2020, 2021a; Osewska, 2012).

Religious Education in Poland fulfills three catechetical functions for students: education, upbringing and religious initiation (Polish Bishops' Conference, 2001b). This takes place at the kindergarten, primary and post-secondary level for two hours a week (Czekalski, 2010; Łaciak \& Szczepankowska, 2013). Religion lessons consist of adapting to educational regulations, while catechesis has more autonomy in relation to the development of curriculum and teaching materials. It seeks to explain that the basic program of catechesis of the Catholic Church in Poland, the curriculum and teaching materials (Polish Bishops' Conference, 2010a; b) are subject to material supervision of the Church and are made available to the Ministry of National Education, however they are not subject to pedagogical supervision and approval (Chrostowski, 2021a; Tomasik, 2010). The above findings have far-reaching implications for Religious Education in schools (Mąkosa, 2014). The main point of reference being the tasks of catechesis, which are defined by the General Directory for Catechesis (Congregation for the Clergy, 1997, no. 86-87): promoting knowledge of the faith, liturgical education, moral formation, teaching to pray, education for community life and missionary initiation. The Catechetical Directory of the Catholic Church in Poland again states that Religious Education should fulfill the educational, informative and initiate function of religion (Polish Bishops' Conference, 2001a, no. 37-53).

Religious Education, through the implementation of the goals of education and upbringing, can contribute to the development of the student as a conscious, informed, and good citizen. The religion lesson is therefore, in a sense, a service to the state and a service to democracy (Dłuska, 2017). In this context, it is also important to pay attention to the unique educational value of religion lessons, not necessarily shared by other school subjects. The primary focus is on religious motivation, as, the mere knowledge of the ethical and moral values underlying modern democracies is not enough just to build right attitudes. In addition, to the intellect, it is necessary to engage emotions and will, the need to motivate, and to interiorize values and to absolutize them. That is, to put their own personal hierarchy of values as most significanct (Mąkosa, 2014).

Furthermore, Religious Education in Poland, in its conceptual and curricular assumptions, adopts the view that the education and upbringing of students are condition for integral human development and their adaptation to life in a pluralist and democratic society (Polish Bishops' Conference, ; b). There are two primary goals for religion lessons that are important, as they influence and shape the attitudes (including political attitudes) of young people. First, it is about information purposes, which facilitates learning about the history of religion, worship and religious practices, and familiarization of the basic religious concepts. Second, the formative goals of Religious Education, which focus on the creation and development of structures for receiving and processing religious knowledge, develop one's

\footnotetext{
3 In May 1990, i.e. four months before the start of the first religion lesson, the declared religiousness of Poles was $94.8 \%$, and in February 1991, i.e. after five months of religion lessons at school, it was $97.4 \%$ (Borowik, 1997; Chrostowski, 2020; 2021a).
} 
own responses to the problems of individual and social life (Dramnescu \& Gokcel, 2014; Polish Bishops' Conference, 2010a, b, 2018, 2019).

Students require not only the competences necessary to actively practice religious worship, but also, and perhaps above all, to be able to distinguish between patterns and antipatterns, values and anti-values that relate to love, compassion and tolerance, and thus ensure harmonious participation in social life (Dramnescu \& Gokcel, 2014; Polish Bishops' Conference, 2010a; Dziekoński, 2010; Tomasik, 2000; Janiga, 2004; Zellma, 2003; Mąkosa, 2010). In this regard, Religious Education in Poland has five main areas of social impact, which are directly related to the functioning of people in a democratic state and the creation of a system for the promotion of democracy (Dłuska, 2017):

(a) Religious Education acquaints students with the fundamental values that are necessary for the presence and action of individuals and groups in society and a democratic state. The state itself is not able to contribute to the creation of these values in society because it would lose its neutrality (Dłuska, 2017; Baniak, 2012a, 2012b; Mariański, 2005).

(b) Religious Education plays an important role in creating integrative legitimating functions. That is, in religion lessons, young people are not only provided with information and values, but also justify these values in a social context (Baniak, 2012a, 2012b; Dłuska, 2017).

(c) During Religious Education, young people are entitled to take responsibility for themselves and other people, and to fulfill specific roles and social tasks, the overarching goal of which is the common good (Baniak, 2012a, 2012b; Dłuska, 2017).

(d) Religious Education helps young people to develop the function of a critical and conscious assessment of reality, resulting from a particular concern for values, people's well-being, the common good and the ability to defend the common good and the democratic form of government (Baniak, 2012a, 2012b; Dłuska, 2017; Osewska, 2012).

(e) Religion lessons promote respect for diversity, inclusive and balanced approaches to individual traditions and help to neutralize harmful stereotypes (Obrycka \& Dąbrowski, 2018; OSCE, 2007).

School teaching of religion is not opposed in any way to the reality of a democratic society, given that Religious Education not only recognizes philosophical and religious pluralism, but also can see positive elements in other religions. It also respects human freedom and its individual path to knowledge of the truth, recognizes the value of secular teachings and their autonomy, and places democracy over other forms of government (Moskal, 2019). Therefore, it is worthwhile to focus further on the interrelationship between populism Christianity and Religious Education in order to understand, to what extent, the right-wing populism is a religious and pedagogical challenge.

\section{Right-wing populism as a religious-pedagogical challenge}

In Poland, regular studies on Populism have been conducted since the transformation after 1989 (Murzańska, 2011). Among the researchers dealing with the topic of Populism, the following achievements stand out: A. Lipiński and Stępińska, 2019a, b, 2020); M. Marczewska-Rytko (1995, 2006, 2011), M. Migalski (2005); A. Moroska (2010); R. Markowski (2004); J. Dzwończyk (2000, 2006); J. Hausner (1992); J. Szacki (2006); R. Pankowski (2010). With the work of Polish scientists, one can notice the awareness of the scope of 
the subject, due to the phenomenon of Populism that cannot be considered only from the political perspective, since Populism is part of a broader sociological and psychological phenomena (Murzańska, 2011).

Dzwończyk (2006) asks what is this "Polish populism"? In response-quoting the interview of Prof. J. Szacki for "Gazeta Wyborcza" of April 23, 2004-Dzwończyk stated that now-in contrast to the 1980s-Populism in Poland is becoming dangerous, because it contests the not fully formed democratic system and calls for rebuilding of "everything" from scratch in the name of particular and often dubious reasons (Dzwończyk, 2006). In this light, the scientific discourse indicates some characteristics of contemporary Polish Populism as including: Poland's political and economic sovereignty, Euroscepticism, a positive image of the Polish nation, anti-communism, anti-elitism, anti-intellectualism, and xenophobia (Przyłęcki, 2012a, 2012b; Stanley \& Cześnik, 2019; Stępińska et al., 2017). These elements also underlie the typology of Populism ${ }^{4}$ among Polish citizens and allow the identification of its three main forms (Jakubowska, 2004; Stępińska et al., 2017): procedural populism (assuming that specialized politicians and political parties themselves do not care about people and that people do not need politicians or political parties); sectoral populism (acceptance of "crusades" against criminals or political elites, etc., and the strong position of the Church and the state), xenophobic populism (arguing that Poland should not be a part of the European Union, and that diplomacy should specifically defend Polish political, economic and cultural sovereignty).

It must not be forgotten that Populism is always strong, where the party systems are weak. In this sense, the Polish party system is only partially institutionalized, which clearly affects the quality and degree of consolidation of democracy in Poland (Tyrała, 2020a, 2020b). As noted by M. Tyrała (2020a, 2020b), the research carried out annually by "Freedom House" and "The Economist" shows that since 2015, democracy in Poland has been gradually moving towards authoritarianism and deviating from the standards of liberal democracy. The "Freedom House" democracy index in 2015 increased negatively from (2.21) to (2.89) in 2018, while "The Economist" democracy index in 2015 decreased negatively from (7.09) to (6.67) in 2017 and 2018. The researcher also emphasizes the fact that the lowering of the level of democracy in Poland was influenced by the actions of the authorities through: politicization of the media, breaking parliamentary procedures, campaigning against non-governmental organizations and taking control of the government over the justice system (Tyrała, 2020a, 2020b). In addition, the "Authoritarian Populism Index" from 2019 indicates that the fourth place in the ranking (after Hungary, Greece and Italy) in terms of support for populists was taken by Poland, which is influenced, among others, by election results and activities of the PiS party (Timbro, 2019).

\footnotetext{
${ }^{4}$ A very lively research interest in this phenomenon in the international arena leads, on the one hand, to the multiplication of interpretative trends, which allows for a multidimensional and aspect approach to the issue and its understanding in relation to populism and its causes (Jörke \& Selk 2017; Marczewska-Rytko, 2011; Westphal, 2020; Woods und Wejnert 2014). On the other hand, this contributes to a certain imprecision of the word, which results in the fact that both a significant part of the society, as well as journalists and scholars, are not sure of its meaning (Dinç, 2016; Hawkins, 2009). It is worth pointing to the typology of populism, the systematization of which was undertaken by Gidron \& Bonikowski (2013) on the basis of three main conceptual assumptions that are present in the scientific literature (Jansen, 2011; Laclau, 2005; Mudde, 2004, 2007; Mudde \& Kaltwasser, 2012, 2017; Panizza, 2005; Roberts, 2006). In this sense, they define populism in three ways: a form of political mobilization, a discursive style, and an ideology (more on this subject in Gidron \& Bonikowski, 2013).
} 
In Poland, as in other European countries, the relationship between Christianity and Populism is evidenced in attitudes towards migration from the Middle East and Africa; Islamic affiliation with terrorist activities; European Union and understanding the independence of individual countries; gender ideology, family, homosexual relationships, etc. (Ahrens \& Rebenstorf, 2018; Courau et al., 2019; Czada \& Musch, 2019; Montgomery \& Winter, 2015; Spencer, 2017; Stanley, 2016; Topidi, 2019; Wagenvoorde, 2019). As Ahrens and Rebenstorf (2018, p. 185) state in their article: "each of these themes is related to at least a few items where the boundaries between the" thin ideology "of Populism and the manifested right-wing ideology are fluid".

Over the past few years (more or less since the immigration crisis in 2015), populist parties in Poland have managed to strategically align the understanding of the country's population with the Catholic inhabitants of Poland, whose identities are argued to be absolutely protected against the dire influence of the elite and outsiders (liberal Europeans, politicians and foreign refugees) (Cremer, 2018; Montgomery \& Winter, 2015; Spencer, 2017; Stanley, 2016; Topidi, 2019; Wagenvoorde, 2019). In this context, the religious beliefs and religiosity of Poles are identified in the populist discourse with a specific "mission" that the Polish nation must fulfill in Europe, the restoration of the leading role of Christianity on the old continent (Topidi, 2019). At the center of their activities, the Polish right-wing populists place their defense on what is Catholic and what is Polish (nationalism), which is reinforced by the slogans of defending the religion represented by the Catholic Church, a strong state, family and tradition (Topidi, 2019).

Regardless of how Populism is defined, it remains certain that it is a religious-pedagogical challenge (Herbst \& Menne, 2020), as right-wing populists contribute to numerous divisions in society (Marzouki et al., 2016; Wagenvoorde, 2019). The susceptibility of Christians to right-wing populism will depend not only on religious affiliation or lack thereof, but also on the person's morality and, above all, on the degree of identification with religion. All these factors clearly influence political views and life status (e.g. income, level of education, age) or individual preferences (Ahrens \& Rebenstorf, 2018; Knutsen, 2004; Verkuten, 2014; Wagenvoorde, 2019; Ysseldijk et al., 2010). In this view, it is necessary to point to several characteristics that emphasize the relationship between Populism and Christianity and Religious Education, and reinforce an understanding of Populism as a religious-pedagogical challenge:

(a) Populist parties instrumentalize religion within its biblical-theological context, which is related to religious doctrine. At first glance, the religious doctrine is built around teaching about the love of another human being (Mk 12: 28-31), but at the same time it contains, as it were, three catalysts in relation to populist, anti-social and fascist attitudes: 1. The doctrine of revelation and related claims for the exclusive possession of the truth; 2 . The doctrine of election, and thus programmed, divides into persons belonging and not belonging to a given religious group; 3 . The question of theocracy or secularity of the state (Rebenstorf, 2018).

(b) Populists use the concept of religious belonging and identity in pluralistic societies by emphasizing homogeneity within a nation, traditions, values, beliefs and life forms. The Church and Religious Education see religious identity as a direct reference to living in harmony with the professed faith and to religious practices (Marzouki et al., 2016; Roy, 2016; Arato \& Cohen, 2017; Wagenvoorde, 2019; Mavelli, 2015; Stankov \& Živković, 
2019; DeHanas \& Shterin, 2018; Molle, 2018; Pickel, 2015, 2018; Schwörer, 2018; Polish Bishops' Conference, 2001a, 2001b, 2010a, 2010b, 2018, 2019).

(c) The level of religiosity that Populists subscribe to is fluid, ambiguous and adjusted to adopted policies (Ahrens \& Rebenstorf, 2018; Huber \& Yendell, 2019; Immerzeel et al., 2013; Rebenstorf, 2018). In this sense, whenever populists speak of Christianity, they use it as a key to indicate the importance of Christian values within the functioning of national civilization. Contrary to the religiosity that actually stems from faith and is encouraged by the Church and formation in Religious Education, the religiosity proposed by populists is essentially aimed at uniting Christians in favour of rejecting what is foreign; for example, the rejection of Islam in Europe (Roy, 2016; Wagenvoorde, 2019). Religion is then harnessed to the realization of goals inconsistent with its essential role (Sołtys, 2015).

(d) Morality is a social system of normative principles that define what is good and what is bad (Gert, 2016). In the actions of populists, morality is aimed at demonizing opponents, moralizing people and disqualifying the elites as completely immoral and corrupt in order to allegedly defend tradition and social order (Arato \& Cohen, 2017). In this sense, the more morally conservative a person is, the more susceptible they are to populist propaganda (Hirsch-Hoefler et al., 2008). Contrary to populists, the Catholic Church and Religious Education focus on the direct transmission of certain virtues and the enhancement in children and adolescents of those traits and behaviors that are socially desirable (Polish Bishops' Conference, 2010a, 2010b, 2018, 2019).

In the above view, all school education, including Religious Education, is not only to enable young people to participate independently in society and to actively participate in shaping democracy, but also to empower young people to take responsibility for themselves and others (Jungkamp, 2017). This problem is significant and for that reason, the biblical-Christian tradition, theological doctrine, spirituality and morality lie at the foundations of the Christian religion and Religious Education. This further provides the ideological foundations of today's democracies, among others in Europe and America (Herbst \& Menne, 2020). From a pedagogical point of view, the question should be asked: what do students learn exactly in this context of religion lessons at schools and what impact this has on their personal participation in social life and strengthening their pro-democratic positions? (Schwendemann, 2016).

\section{Possibilities of strengthening prodemocratic positions during the religion lessons}

The answer to the above question is possible, perhaps based on the theoretical analysis of the content of the curriculum of Religious Education of the Catholic Church in Poland (hereinafter PPK) (Polish Bishops' Conference, 2010a, 2018). This curriculum contains references for the creation of programs of religion lessons for all educational levels and all types of schools in Poland (Szept, 2003). The Polish Bishops implemented the religious content at the two levels: kindergarten/primary schools, and at the secondary level schools (Polish Bishops' Conference, 2010a, 2018). At the two stages, one important task of Religious Education is to promote democracy on the basis of postulates related to moral and social education (Dziekoński, 2010). 


\subsection{Kindergarten and primary schools}

At the kindergarten level, children are already encouraged to develop their sense of responsibility for others (Dziekoński, 2010). According to the authors of the PPK, the religious socialization of a child is usually related to the image of adult religiousness at the immediate vicinity (e.g., parents, siblings, grandparents) without assuming a child's autonomous religiosity. Currently, educational activities are focused on the child's natural experiences as they form the basis of gradual religious initiation and social integration. At this stage of education, it is important for the child to develop a child-friendly relationship with people, which is also associated with combining the right image of God (close, present, full of love for people and caring for everyone). This is the requirement to treat other people with love in situations of disagreement, misunderstandings or conflicts (Polish Bishops' Conference, 2010a, 2018). This goal has been observed in grades I-III of primary school which translates the sacraments of Penance and the Eucharist into reality (Dziekoński, 2010), in which the child arouses a longing for security, peace and the satisfaction of positive desires, the source of which is God. The main role in shaping a religious attitude, is to build trust and a sense of security in interpersonal relationships, which then the child can transfer his own relationship with God and other people. In addition, as part of the design of the molar posture, students deepen their understanding of the Decalogue, which should significantly improve the smooth functioning of society (Polish Bishops' Conference, 2010a, 2018).

Within the grade levels of IV-VIII of primary school, there is a transition from authoritarian religiosity to an attempt to build and bring on a personal contact with God. During these religion lessons it is important to bring out and shape the right social attitude by performing the following tasks: reflective attitude towards the other person and their nature, various life situations and the immediate environment; improving the ability to express oneself and assess social and religious phenomena at the school and local community level (Polish Bishops' Conference, 2010a, 2018).

Additionally, in grades IV-VIII of the primary school, there is a relationship between religion lessons, the Polish language, history, and the knowledge about society and art. These school subjects with varying degrees of intensity, introduce students to the field of European culture (Dziekoński, 2010; Polish Bishops' Conference, 2010a). Religious Education curricula complements teachings with history lessons and the school subject "Knowledge about Society", among others, as part of the implementation of the following thematic areas: reflection on oneself and the social environment (e.g. diversity and uniqueness of people, acceptance of various human needs; rights and obligations of individual family members; social justice; kindness and tolerance; conflict resolution methods); region (eg. historical-cultural and socio-economic problems; area of activity and type of public authorities); homeland (e.g. the most important national holidays; state symbols; national and ethnic minorities); the state (e.g. the democratic nature of the Polish state; free elections; freedom of speech, media and press; the Constitution of the Republic of Poland; rights and obligations of citizens); society (the importance of work in human life; various social groups and their role in society; problems of contemporary Poland); European community (participation and role of Poland in the European Community); human problems (advantages and disadvantages of using electronic media; examples of causes and effects of armed conflicts in the world) (Polish Bishops' Conference, 2010a, 2018). 


\subsection{Secondary schools}

In the context of religion lessons in secondary schools, the PPK points out that the increased intellectual development of young people leads to the disintegration of harmonious worldviews from childhood. Young people begin to critically perceive or analyze the surrounding reality which leads to a distortion of their world of values. An attempt to develop an objective, critical view of the world and the surrounding reality runs the risk of moral relativism (Polish Bishops' Conference, 2010a, 2018). Therefore, Religious Education in this phase focuses on shaping awareness, moral attitudes and self-esteem. Based on this knowledge, students acquire the ability to evaluate their moral behaviour, develop relatively stable behaviours and cognitive responses motivated by emotionally experienced highest values and relate them to love for the family, homeland, the Church and for God and their own person. It is also about achieving a certain holistic integration of physical, spiritual, intellectual, emotional and religious life (Polish Bishops' Conference, 2010a, 2018). It is also important for students to get to know the relationship between citizens and the authorities in democratic, totalitarian and authoritarian systems. In addition, students will also learn the importance of the values of patriotism ${ }^{5}$ and national community, with the analysis and interpretation of biblical social and patriotic themes. Furthermore, students are introduced to the meaning and differences in definitions of such concepts such as state, nation, national identity and love for the homeland. Particular attention is paid to the subject of democracy which demands the presence of values in the entire state structure. An important part of religion lessons is also to reflect the duties of a person as a member of society and citizen, as well as the tasks related to the social and apostolic commitment of Christians. It can also deal with issues of solidarity, compassion, commitment to volunteering and the social value of celebration (Dziekoński, 2010; Polish Bishops' Conference, 2010a, 2018).

The final stage within school education is to prepare secondary school students to assume the role of adults in their social life. Teaching religion fulfills this task which is to help young people find their place in the world, democratic society, family and the Church community. In this educational phase, young people prepare themselves in a special way to define their own professional roles so that Religious Education deals with topics related to the broadly understood Christian vocation, work and unemployment. It is also important to expand students' competences so that they can not only analyze the phenomena occurring in society, but also make a critical assessment of them. Additionally, many topics focus on the issues of permanent Christian formation, as well as specific issues such as the pathology of social life, mass media, bioethics, and the ethics of marriage. Another group of topics are didactic classes that deal with the issues of pluralistic culture in the regional and European context (Polish Bishops' Conference, 2010a, 2018; Dziekoński, 2010).

Religion lessons, at all levels of school education should learn to critically evaluate extreme attitudes such as nationalism, cosmopolitanism, chauvinism or any kind of fundamentalism in connection with the development of a generally understood social and

\footnotetext{
5 The term patriotism refers to the concept of "patria" or "homeland" and means love for what constitutes the homeland, that is, love of history, tradition, language or the homeland itself. It is a love that also includes the works of compatriots and the fruits of their genius (Tomasik, 2019). Not to be overlooked is also the fact that the terms "patriotism" and "nationalism" are often confused. M. Brzozowska emphasizes that nationalism has a doctrinal character and includes the belief that the nation is in some way the central principle of political organization. Patriotism, on the other hand, is the affective basis for this belief (Brzozowska 2009).
} 
religious life (Janiga, 2004). Attitudes such as patriotism, service to society and openness to other people reflect Christian values and the basis of the basic program of Religious Education for Catholics (Pontifical Council for Promoting the New Evangelization, 2020; Polish Bishops' Conference, 2010a, 2018). In this regard, Religious Education aims at pro-democratic positions, integrates culture and faith, and leads to the internalization of Christian values and tolerance towards other people (Zellma, 2003). It is also essential to convey knowledge about ethical and moral values, both in the context of the individual and the social life of democratic societies. Many religion lessons are about justice and love for others, family members, friends and neighbours, as well as for people of other religions, nationalities, and cultures. Much importance is also devoted to patriotism in the local, national and state context, as well as to European integration. Therefore, during religion lessons, knowledge about the principles of proper functioning in a democratic society is taught (Mąkosa, 2010).

\section{Point of tension: doctrinal-ideological problems between Catholic Church and school catechesis versus human rights and democracy}

The "Toledo Guiding Principles" are respected in Poland. These protect religion lessons from all kinds of political or radical influences on its legal framework, content and tasks (OSCE, 2007), and the Catholic Church itself considers democracy to be the leading form of government (Baniak, 2012a, 2012b; Świątek, 2008). The above analysis of the possibilities of strengthening pro-democratic positions during religion lessons also confirm this fact as well. However, this does not change the fact that with regards to the right-wing populism, one should critically highlight the point of tension in the relationship between Catholic Church and school catechesis versus human rights and democracy in Poland. This can also be understood as a doctrinal-ideological problem, which includes, among others, the following three main and complex problems:

- The general analysis of the goals of confessional school catechesis (Polish Bishops' Conference, 2001a, 2001b, 2010a, 2010b, 2018, 2019) indicates an identical formula, the essence of which is the Revealed Truth (Mąkosa, 2010, Orczy 2009) and it is precisely to its message that the goals of Religious Education are reduced. In a pluralistic and democratic society, the doctrine of the Revealed Truth, as soon as it becomes a school subject and imposes itself on students, raises didactic and educational problems (Cackowska \& Stańczyk, 2012). There is also a difficulty as to the fear of accusations of indoctrination and moralizing in religion lessons (Olbrycht, 2012). In this approach, the formation of students is open to cultural, religious and social pluralism and its understanding becomes more difficult (Cackowska \& Stańczyk, 2012; Milerski, 2002).

- The Catholic Church teaches that the homosexual act is morally wrong (Catechism of the Catholic Church, no. 2357-2359), while in itself "the inclination of a homosexual person" is not a sin, but a weaker or stronger propensity to do evil from a moral point of view (Narewska, 2015). Open criticism of the LGBT communities by church hierarchs in Poland, ${ }^{6}$ as well as critical religious content regarding the phenomenon of homo-

\footnotetext{
6 An example of such a statement is the sermon by Archbishop M. Jędraszewski (bishop of the Archdiocese of Krakow) about the "rainbow plague" which was offensive and clearly deprecating non-heteronormative people (LGBT); more on this topic: Chadwick, 2019; Vasileiou, 2021.
} 
sexuality, contribute to the intensification of the populist attitude that homosexuality and the LGBT movement are a threat to Christian civilization and Polishness (Górska, 2020). In this sense, the LGBT movement, which in the opinion of PiS and some Bishops of the Catholic Church in Poland, ${ }^{7}$ is becoming a universal symbol of evil and threat, and rises to the rank of a universal enemy, which is an old populist practice of totalitarian systems, as a mechanism for uniting supporters, fermenting hostility and justifying one's own mistakes (Pilch, 2020).

- On the one hand, the promotion of patriotic attitudes and a sense of national awareness by the Catholic Church in Poland is a positive phenomenon, because the love of the homeland, native culture and tradition does not only concern the past but is closely related to today's ability to build the common good in solidarity (Polish Bishops' Conference, 2017). On the other hand, although the Church in Poland condemns egoistic nationalism (Polish Bishops' Conference, 2017), it is accused of teaching national chauvinism in many churches and in many school classes (Piwnicki, 2017).

The implementation of Religious Education in the face of the above problems is important. However, it should never be through indoctrination, imposition, automatic implementation, but through the subjective creation of learning, experiencing, implementing Christian values and dialogue (Chałas, 2017). When teaching religion lessons, teachers cannot remain in a fundamentalist position, as they doom themselves to helplessness, and show maladjustment and anachronism to the challenges of modern democracy (Cackowska \& Stańczyk, 2012). It is necessary to revise the school curriculum that teaches religion in terms of a critical approach to the Revealed Truth within the framework of inter-religious dialogue and promotion of human rights such as with democratic rights for refugees or LGBT people. In addition, a broader idea of patriotism should also be developed. That is, open European patriotism, which would be able to counter the hostile social dichotomies created by populists (Piwnicki, 2017).

\section{Cues for educational practice}

It is not enough in Religious Education to familiarize students with information and content on Populism. The very transfer of knowledge is just the beginning. It is imperative to deal with racist and xenophobic prejudices in societies, conspiracy theories, and to understand the historical and socio-political context of the actions of populists. It should be emphasized that in this context, all schools and Religious Education experiences have two basic meanings: on the one side, education means a pedagogical effort to "educate" children, adolescents and adults, and on the other side, it must support individuals to take responsibility for combating populist exaggeration (Danner, 2017, 2020). Religious Education cannot be understood by only looking through a narrow lens but rather it must be always understood broadly as a cognitive understanding and critical confrontation with the world, as well as developing a personal definition of one's own position and orientation in the world, the aim of which is to change a person's mental views and as a person.

\footnotetext{
7 The curriculum for teaching religion in Poland, published by the Polish Bishops' Conference in 2010 and 2018, contains only the official teaching of the Catholic Church on homosexualism and it does not contain narrow and aggressive references to homosexuality (Polish Bishops' Conference, 2010a, 2018).
} 
However, in order to achieve such a goal, it is necessary in Religious Education to intellectually explain the situation, and to establish a personal relationship with it by accepting or negatively evaluating a given phenomenon (Danner, 2017).

In a practical sense, within Religious Education (e.g. in secondary schools) the thematic components should be built around the following traits (Matuschek \& Morcos, 2016a):

(a) What is right-wing populism, how does it use religion for its purposes, what dilemmas lie behind it and what can it lead to?

(b) Exposing the right-wing populists by explaining their ideological basis and showing concrete examples of the instrumentalization of religion by populists. It is important to dismiss the "messianic" image that publicly right-wing populists have.

(c) Indicating the possibility of actively defending democracy and emphasizing the role and functions of right-wing populist parties as opponents of democracy and "hijackers" of religion (Marzouki et al., 2016). It is about a positive discussion of the principles of democracy, their alignment with Christianity and showing what they mean for a peaceful and open co-existence in society.

Religion lessons in which populism is an important issue must be guided by several principles, including the use of intelligible language; emotional communication of facts; showing students recognition and respect; concern for dialogue and change of perspective; clarity of argumentation; striving to create a platform for integration; creativity (Matuschek \& Morcos, 2016a).

The practical implementation of the lesson components based on these principles aims to position students with a critical review of right-wing populist strategies and patterns of action in terms of their relationship with religion. In this sense, in order to increase the effectiveness of the message and absorption of content by students, it is necessary to explain the following four steps around which the anti-democratic positions of right-wing populists are constructed (Matuschek \& Morcos, 2016b):

Step 1: Right-wing populists identify enemy images with individuals, groups of people or institutions that have already encountered religious suspicion or prejudice (e.g. homosexuals, Muslims, European Commission-identified as an organ of "liberal pressure").

Step 2: Populists shift responsibility for all problems in democracies to groups of "enemies" that threaten Christian order and values. The enemy's images, however, are flexible and varied and adapt to the problem presented by right-wing populists.

Step 3: Populists try to isolate themselves and Christians from self-identified "enemies", such as politicians from other parties or refugees and advocate strict policy measures such as closing borders by Middle East refugees to contain alleged threats associated with the destruction of Christian culture. Any criticism of the gift arguments by the right-wing populists only confirms the evil of their imaginary enemy.

Step 4: It should be remembered that if the third step does not produce the desired result, the right-wing populists repeat it in a more radical form, and then all secular and religious critics become enemies who are blamed for any failure.

In this context, the main practical goal of Religious Education must have a positive meaning, creation in shaping the image of the future, which should be built around the following elements: meaning - a well-defined idea of a future worth living in, based on Christian values and giving meaning to the peaceful co-existence of people of different world views, religions, sexual orientations, etc.; perspective-faith as the basis of 
Christian life, which gives strength in moments of uncertainty and motivates to honest performance and activity for building an open society and making one's own life, country and world better; emotions-passionate and faith-based effort to overcome social divisions, ensure equal educational opportunities and constantly inspire students to build a democratic Europe and a democratic world where there is a place for everyone (Matuschek \& Morcos, 2016a).

Ultimately, it should be remembered that despite the fact that Religious Education in Polish schools is confessional teaching with clearly defined addressees (followers of a given religion), it must focus not only on shaping a positive relationship towards a specific religious option, but also provide objective knowledge and a variety of information on other religions as well as cultural and social processes in a given country (Milerski, 2009). In the current situation, when the lesson of religion in Polish schools has the character of a confessional school catechesis (Polish Bishops' Conference, 2001b), it is also important to teach the six tasks of catechesis (Congregation for the Clergy 1997, no. 86-87; Polish Bishops' Conference, 2001a, no. 23-30), which can take the following forms in relation to counteracting Populism:

- Promoting knowledge of the faith-first, it is about acquiring religious content in such a way as to acquire the ability to interpret one's life according to the depth of Christ's thoughts (Polish Bishops' Conference, 2001a, no. 24), which oscillates around teaching about love of others (Mk 12, 28-31). Faced with the challenges of Populism, religion cannot be viewed as a simplified description of reality and students should be encouraged to constantly seek the truth and confront it with populist lies and manipulations.

- Liturgical education-it is carried out through teaching that explains the understanding of the Christian faith, the ways of celebrating it, and the participation in the liturgy itself (Polish Bishops' Conference, 2001a, no. 25). Such a wide spectrum engages this function of catechesis which allows for the conceptualization of devotion plans during religion lessons and outside lessons and celebrating them together with students. The central themes of such services may be related to issues of pro-democratic values that contradict the actions of Populists, for example, social justice and solidarity, acceptance and tolerance.

- Moral formation - it is about the formation of conscience, because the mere knowledge of what is morally good and what is bad is not enough. It is also important to develop human values while supporting the educational process of school and family. With the increase in populist attitudes in societies, it should be born in mind that the educational ideal in the human formation of a Christian cannot be lowered to an average or mediocre level (Polish Bishops' Conference, 2001a, no. 26). The challenges faced by today's democratic states require students to firmly defend Christian values, which, in a way, feed on European democracies (Baniak, 2012a, 2012b; Dłuska, 2017; Mariański, 2005).

- Teaching to pray-apart from introducing private and common prayer into the practice of prayer, Religious Education also teaches knowledge about prayer and shows its meaning in the context of human life (Polish Bishops' Conference, 2001a, no. 27). In this sense, in the face of Populism, it is important to use positive forms of popular piety, to which students are especially attached, because, as empirical research shows, religious practice is a kind of "umbrella" protecting against Populism (Turska-Kawa \& Wojtasik, 2020).

- Education for community life - the task of school catechesis is to prepare students not only to make the right choices in various areas of social and political life, but also to 
fully participate in public life, by sharing with them the values rooted in the Gospel (Polish Bishops' Conference, 2001a, no. 28). In this sense, Populism should be understood as a contradiction of the Christian understanding of community life, because it rejected and discriminated other people, such as refugees (Herbert, 2019; TurskaKawa \& Wojtasik, 2020). Education for community life must point to an open society in which, in the name of love of others (Mk 12: 28-31), there is room for every human being, regardless of origin, culture, religion or sexual orientation (Herbst \& Menne, 2020).

- Missionary initiation - the missionary responsibility of students must be expressed primarily in giving testimony, so it should enable students to be present as Christians in professional, cultural, social and political life (Polish Bishops' Conference, 2001a, no. 29). In the face of Populism, religion classes are a place where students can and must be sensitized to their Christian mission in the world.

All the above-mentioned tasks of catechesis are essential in educating against Populism and constitute a rich, varied and multi-faceted whole. Each of them, in their own way, realizes the overarching goal of catechesis in the face of the challenges related to Populism. Therefore, each of these tasks should be considered in defining specific goals and constructing catechetical programs for people of different ages and different environmental contexts (Polish Bishops' Conference, 2001a).

\section{Conclusions}

Religious Education in Polish schools is not only the transmission of the dogmatic, moral and liturgical tradition of the Church and the promotion of this tradition, but also broadly understood as "formation in the field of spiritual culture, i.e. science, morality, artistic and technical skills, and physical culture" (Moskal, 2019: 41). This is to help in shaping citizens who are responsible for themselves, other people and the environment, but also to be aware of their rights and obligations in a democratic state.

In addition, Religious Education, where Populism is an important issue, not only helps shape a Christian worldview but also supports the development of attitudes that will enable students to discover populist lies, manipulations and make them aware of how Populists use religion for their anti-social purposes (Chrostowski, 2021b). Such lessons help to educate students, who are sensitive to the content used in public debate by Populists, and equip them with tools and skills for rational and forward thinking, so they are better equipped in dealing with them. The main point to be addressed here is to educate Christians who are aware of their vocation in the world and committed to justice and social solidarity and who will uphold the rights of the most vulnerable and those discriminated against.

Subsequently, it should be noted that the authors of the curriculum of Religious Education in Poland, in the introduction to this document, stated that many students participating in religion lessons had not yet reached maturity. This reality does not favour important life decisions and instead hinders the achievement of the adopted goals by each person on the same level (Polish Bishops' Conference, 2010a, 2018). Therefore, the level of education will not always be related to the pro-social moral or political functioning of a given person. As such, it is a complex problem, which generally exists in the discrepancy between values - also non-religious (in secular education) and human functioning, because 
various factors play a significant role here (e.g. personality, family or peer environment, etc. (Chutorański, 2012; Czyżowska \& Czyżowska, 2018; Groth, 2007; Zybała, 2019).

However, even the emergence of such a problem by some students does not release those responsible for Religious Education from searching for new and more effective forms of civic formation; the foundation of which is and must always be the promotion of pro-democratic positions. Regardless of the personality, family or peer and/or cultural background of a student, he or she must be equipped with tools that enable him or her to critically reflect on what right-wing Populists say and propagate. In addition, it is the position of individual people and their views "for" or "against" right-wing Populists that will determine the fate of future generations and the democratic development of societies, as well as the peaceful co-existence of followers of different religions.

Authors' contributions Not applicable.

Funding Open Access funding enabled and organized by Projekt DEAL. Not applicable.

Availability of data and material Not applicable.

Code availability Not applicable.

\section{Declarations}

Conflict of interest The author declares that he has no conflict of interest.

Open Access This article is licensed under a Creative Commons Attribution 4.0 International License, which permits use, sharing, adaptation, distribution and reproduction in any medium or format, as long as you give appropriate credit to the original author(s) and the source, provide a link to the Creative Commons licence, and indicate if changes were made. The images or other third party material in this article are included in the article's Creative Commons licence, unless indicated otherwise in a credit line to the material. If material is not included in the article's Creative Commons licence and your intended use is not permitted by statutory regulation or exceeds the permitted use, you will need to obtain permission directly from the copyright holder. To view a copy of this licence, visit http://creativecommons.org/licenses/by/4.0/.

\section{References}

Ahrens, P. A., \& Rebenstorf, H. (2018). Rechtspopulismus unter evangelischen Christen - empirische Befunde der Kirchen- und Religionssoziologie. Zeitschrift Für Evangelische Ethik, 62, 183-199.

Antoszewski, A. (2012). Demokratyzacja w Polsce w świetle współczesnej tranzytologii. In Ł Danel \& J. Kornaś (Eds.), Dylematy polskiej demokracji (pp. 21-40). Fundacja Gospodarki i Administracji Publicznej.

Arato, A., \& Cohen, J. L. (2017). Civil society, populism and religion. Constellations: an International Journal of Critical and Democratic, 3, 283-295.

Baniak, J. (2012a). Religia i Kościót w społeczeństwie demokratycznym i obywatelskim w Polsce: między losem a wyborem. Wydawnictwo Naukowe WNS UAM.

Baniak, J. (2012b). Wprowadzenie: Demokracja i społeczeństwo obywatelskie a religia i Kościół. In J. Baniak (Ed.), Religia i Kościót w społeczeństwie demokratycznym w Polsce (pp. 7-20). Wydawnictwo Naukowe WNS UAM.

Borowik, I. (1997). Procesy instytucjonalizacji i prywatyzacji religii w powojennej Polsce. Wydawnictwo Uniwersytetu Jagiellońskiego.

Brzozowska, M. (2009). Patriotyzm i nacjonalizm w polskim dyskursie ideologicznym. Etnolingwistyka, $21,103-120$.

Cackowska, M., \& Stańczyk, P. (2012). Katecheza szkolna - między demokracją a teologią zstępującą. Teraźniejszość - Człowiek - Edukacja: Kwartalnik Myśli Społeczno-Pedagogicznej, 1(57), 19-38. 
Chadwick, L. (2019). Archbishop warns of 'rainbow plague' amid LGBT tensions in Poland. Retrieved September 11, 2021, from https://www.euronews.com/2019/08/02/archbishop-warns-of-rainbow-plagueamid-lgbt-tensions-in-poland.

Chałas, K. (2017). Wartości w programie wychowawczym szkoty stużace integralnemu rozwojowi $i$ wychowaniu ucznia. Ośrodek Rozwoju Edukacji.

Chrostowski, M. (2020). Edukacja religijna w Polsce: Czas na zamianę? Łódzkie Studia Teologiczne, 29(3), 39-52.

Chrostowski, M. (2021a). Schulpastoral für alle! Religionspädagogische und pastorale Impulse deutscher Schulpastoral für ein schulpastorales Modell in Polen (am Beispiel der Diözese Łomża). NY: LIT Verlag.

Chrostowski, M. (2021b). „Bezbożny sojusz”? populizm i wiodące religie monoteistyczne. Przeglad Politologiczny, 2, 89-103.

Chutorański, M. (2012). Moralność, rozwój moralny, wychowanie moralne. Teraźniejszość - Cztowiek Edukacja, 2(58), 97-106.

Cooperman, A., Sahgal, N., Schiller, A. (2017). Religious Belief and National Belonging in Central and Eastern Europe. Pew Research Center. Retrieved January 20, 2021, from http://assets.pewresearch. org/wp-content/uploads/sites/11/2017/05/15120244/CEUP-FULL-REPORT.pdf.

Courau, T. M., Abraham, S., \& Babić, M. (2019). Populism and Religion. UK: SCM Press.

Cremer, T. (2018). Defenders of the Faith: Why right-wing populists are embracing religion. New Statesman. Retrieved May 10, 20201, from https://www.newstatesman.com/2018/05/defenders-faith-0.

Czada, R., \& Musch, E. (2019). Der Januskopf des Populismus. Praktische Theologie, 54(2), 69-75.

Czapnik, S. (2017). Śladami Hitlera? Skrajnie nacjonalistyczny populizm prawicy w Polsce. Studia Krytyczne, 5, 48-62.

Czekalski, R. (2010). Rys historyczny lekcji religii katolickiej w Polsce. Studia Katechetyczne, 7, 99-125.

Czyżowska, N., Czyżowska, D. (2018). Edukacja moralna czyli o sposobach wspierania rozwoju moralnego uczniów. Retrieved February 11, 2021, from https://ruj.uj.edu.pl/xmlui/bitstream/handle/item/60462/ czyzowska_czyzowska_edukacja_moralna_czyli_o_sposobach_wspierania_2018.pdf?sequence=1\& is Allowed $=\mathrm{y}$.

Danner, H. (2020). Bildung als Widerstand gegen Populismus. Retrieved January 18, 2021, from https:// wbg-community.de/themen/helmut-danner-bildung-als-widerstand-gegen-populismus.

Danner, H. (2017). Bildung angesichts Fremdenfeindlichkeit und Populismus. Vierteljahrsschrift Für Wissenschaftliche Pädagogik, 93(4), 508-525.

DeHanas, D. N., \& Shterin, M. (2018). Religion and the rise of populism, Religion. State \& Society, 46(3), 177-185. https://doi.org/10.1080/09637494.2018.1502911

Dinç, P. (2016). Mapping Populism: Definitions, Cases, and Challenges to Democracy. Istanbul: Istanbul Policy Center.

Dłuska, K. (2017). Nauka religii w szkole publicznej - kościelny przywilej czy służba demokracji? NURT SVD, 2, 336-353.

Dramnescu, M., Gokcel, R. (2014). Moral Education Between Ideal and Populism, International Multidisciplinary Scientific Conference on Social Sciences and Arts. International Multidisciplinary Scientific Conference on Social Sciences and Arts SGEM2014. (825-832). https://doi.org/10.5593/SGEMS OCIAL2014/B11/S3.106

Dudek, A. (2004). Reglamentowana rewolucja. Rozkład dyktatury komunistycznej w Polsce 1988-1990. Poland: Wydawnictwo ARCAN.

Dziekoński, S. (2010). Wychowanie jako zadanie szkolnej lekcji religii katolickiej. Studia Katechetyczne, 7 , $149-165$.

Dzwończyk, J. (2000). Populistyczne tendencje w społeczeństwie postsocjalistycznym. Na przykładzie Polski. Poland: Wydawnictwo Adam Marszałek.

Dzwończyk, J. (2006). Postawy populistyczne w społeczeństwie polskim. Zeszyty Naukowe Akademii Ekonomicznej w Krakowie, 706, 27-42.

Congregation for the Clergy, (1997). General Directory for Catechesis. United States Catholic Conference.

Gert B. (2016). The Definition of Morality. Retrieved February 22, 2021, from https://plato.stanford.edu/ entries/morality-definition/.

Gidron, N., Bonikowski, B. (2013). Varieties of Populism: Literature Review and Research Agenda. Retrieved January 9, 2021, from, https://scholar.harvard.edu/files/gidron_bonikowski_populismlitrevi ew_2013.pdf.

Górska, P. (2020). Efekt „tęczowej zarazy”? Centrum badań nad uprzedzeniami, Poland: Postawy Polaków wobec osób LGBT w latach 2018-2019.

Groth, J. (2007). Rozwój moralny a tożsamość. Edukacja i Dialog, 6, 17-22. 
Hanley, S., Dawson, J. (2017). Poland was never as democratic as it looked. Foreign Policy. Retrieved March 18, 2021, from https://foreignpolicy.com/2017/01/03/poland-was-never-as-democratic-as-itloo ked-law-and-justice-hungary-orban/.

Hausner, J. (1992). Populistyczne zagrożenie w procesie transformacji społeczeństwa socjalistycznego. Germany: Friedrich Ebert Stiftung.

Hawkins, K. A. (2009). Is chavez populist?: measuring populist discourse in comparative perspective. Comparative Political Studies, 42(8), 1040-1067.

Herbert, D. (2019). Religion and the dynamics of right wing populism in Poland: Impacts, causes, prospects. Religion and Society in Central and Eastern Europe, 12(1), 23-37.

Herbst, J.-H., \& Menne, A. (2020). Vox populi vox dei? Theoretische Anhaltspunkte für religiöse Bildung in populistisch aufgeladenen Zeiten. Theo-Web, 19(2), 167-182.

Hirsch-Hoefler, S., Canetti, D., \& Pedahzur, A. (2008). Two of a kind? Voting motivations for populist radical right and religious fundamentalist parties. Electoral Studies, 29, 678-690. https://doi.org/10. 1016/j.electstud.2010.07.003

Huber, S., \& Yendell, A. (2019). Does Religiosity Matter? Explaining rightwing extremist attitudes and the vote for the Alternative for Germany (AfD). Religion and Society in Central and Eastern Europe, 12(1), 63-82.

Immerzeel, T., Jaspers, E., \& Lubbers, M. (2013). Religion as catalyst or restraint of radical right voting? West European Politics, 36(5), 946-968.

ISKK. (2020). Annuarium Statisticum Ecclesiae in Polonia AD 2020. Poland: Instytut Statystyki Kościoła Katolickiego SAC.

Jackson, R. (2015a). Misrepresenting religious education's past and present in looking forward: Gearon using kuhn's concepts of paradigm, paradigm shift and incommensurability. Journal of Beliefs \& Values, 36(1), 64-78.

Jackson, R. (2015b). The politicisation and securitisation of religious education? a rejoinder. British Journal of Educational Studies, 63(3), 345-366.

Jakubowska, U. (2004). Zainteresowanie polityką i postrzeganie własnej sytuacji życiowej a postawy populistyczne. In R. Markowski (Ed.), Populizm a demokracja (pp. 73-202). Instytut Studiów Politycznych Polskiej Akademii Nauk.

Janiga, W. (2004). Wychowanie patriotyczne dzieci w świetle "Dyrektorium katechetycznego i podstawy programowej Katechezy Kościoła Katolickiego w Polsce.” Resovia Sacra. Studia TeologicznoFilozoficzne Diecezji Rzeszowskiej, 11, 213-225.

Janiga, W., \& Mezglewski, A. (2001). Nauczanie religii w szkołach publicznych. Roczniki Nauk Prawnych, 9, 131-160.

Jansen, R. S. (2011). Populist mobilization: A new theoretical approach to populism. Sociological Theory, 29(2), 75-96.

Jörke, D., Selk, V. (2017). Theorien des Populismus zur Einführung. Junius.

Jungkamp, B. (2017). Vorwort. In B. Jungkamp, M. John-Ohnesorg (Eds.), Politische Bildung in der Schule. Zeitgemäße Ansätze in Zeiten des Populismus (5-6). Friedrich Ebert Stiftung.

Kasprowicz, D. (2017). Populistyczna radykalna prawica jako obszar badawczy. Poland: Instytut Dziennikarstwa Mediów i Komunikacji Społecznej Uniwersytet Jagielloński.

Knutsen, O. (2004). Religious denomination and party choice in Western Europe: A comparative longitudinal study from eight countries. International Political Science Review, 25(1), 97-128.

Łaciak, B., \& Szczepankowska, U. (2013). Analiza podręczników do religii w szkołach gimnazjalnych $i$ ponadgimnazjalnych oraz treści religijnych $w$ podręcznikach do języka polskiego $w$ gimnazjach. Poland: Instytut Spraw Publicznych.

Laclau, E. (2005). On Populist Reason. Verso.

Lipiński, A., \& Stępińska, A. (2019a). Rechter Populismus in Polen. In J. Harper (Ed.), Polens Streit um die Erinnerung. Essays zur Illberalität (pp. 93-110). Germany: Tectum Verlag.

Lipiński, A., \& Stępińska, A. (2019b). Polish right-wing populism in the era of social media. The unexpected careers of P. Kukiz and J. Korwin-Mikke. Problems of Post-Communism, 69, 71-82.

Mąkosa, P. (2010). Podstawowe funkcje podręcznika do nauczania religii. In M. Zając (Ed.), Katecheza w szkole wspótczesnej (pp. 167-181). Polihymnia.

Mąkosa, P. (2014). Szkolna lekcja religii istotnym elementem wychowania w szkole. In R. Chałupniak, T. Michalewski, \& E. Smak (Eds.), Wychowanie w szkole: Od bezradności ku możliwościom (pp. 351-361). Redakcja Wydawnictw Wydziału Teologicznego UO.

Marczewska-Rytko, M. (1995). Populizm: teoria i praktyka polityczna. Wydawnictwo Uniwersytetu Marii Curie-Skłodowskiej

Marczewska-Rytko, M. (2006). Populizm na przełomie XX i XXI wieku: panaceum czy putapka dla wspótczesnych społeczeństw. Wydawnictwo Adam Marszałek. 
Marczewska-Rytko, M. (2011). Teoretyczne aspekty współczesnego populizmu. Krakowskie Studia Międzynarodowe, 4, 21-31.

Mariański, J. (2005). Kościół katolicki w Polsce a życie społeczne. Studium socjologiczno-pastoralne. Gaudium: Wydawnictwo.

Markowski, R. (2004). Populizm a demokracja. Wydawnictwo ISP PAN.

Marzouki, N., McDonnell, D., \& Roy, O. (2016). Saving the People: How Populists Hijack Religion. UK: C. Hurst \& Co Publishers.

Matuschek, K., Morcos, S. (2016b). MuP-Praxishilfe: Rechtspopulismus durchschauen und Paroli bieten! Zusammenhänge verstehen und demokratisch handeln. Retrieved March 10, 2021, from http://library.fes.de/pdf-files/akademie/mup/13663-20190225.pdf.

Matuschek, K., Morcos, S. (2016a). MuP-Praxishilfe: Haltung und Handeln für demokratische Werte. Was Politik und Zivilgesellschaft tun können. Retrieved March 10, 2021, from http://library.fes.de/ pdf-files/akademie/mup/13662-20190225.pdf.

Mavelli, L. (2015). Europe's identity crisis, Islam in Europe, and the crisis of European secularity. In R. Tottoli (Ed.), Routledge Handbook of Islam in the West (pp. 185-197). Routledge.

Migalski, M. (2005). Populizm. Wydawnictwo Instytutu Regionalnego.

Milerski, B. (2009). Edukacja religijna w szkole neutralnej światopogladowo. Retrieved April 8, 2021, from https://ekumenia.pl/content/uploads/2014/03/Edukacja-religijna-w-szkole-neutralnej-swiat opogladowo-B.Milerski.pdf.

Milerski, B. (2002). Cele edukacji religijnej w kontekście pluralizmu. Paedagogia Christiana, 2(10), 9-24.

Molle, A. (2018). Religion and right-wing populism in Italy: Using 'Judeo-Christian roots' to kill the European Union, Religion. State and Society, 47, 151-168. https://doi.org/10.1080/09637494.2018.15322 66

Montgomery, K. A., \& Winter, R. (2015). Explaining the religion gap in support for radical right parties in Europe. Politics and Religion, 8, 379-403. https://doi.org/10.1017/S17550483150002921755-0483/ 15

Moroska, A. (2010). Prawicowy populizm a eurosceptycyzm (na przykładzie Listy Pima Fortuyna w Holandii i Ligi Polskich Rodzin w Polsce). Wydawnictwo Uniwersytetu Wrocławskiego.

Moskal, P. (2019). Problem edukacji religijnej w społeczeństwie pluralistycznym. Forum Pedagogiczne, 1, $37-45$.

Mudde, C. (2004). The Populist Zeitgeist. Government and Opposition, 39(4), 542-563.

Mudde, C. (2007). Populist radical right parties in Europe. Cambridge University Press.

Mudde, C., \& Kaltwasser, C. R. (2012). Populism in Europe and the Americas. Cambridge University Press.

Mudde, C., \& Kaltwasser, R. (2017). Populism. Oxford University Press.

Munck, G. L. (2014). What is democracy? A reconceptualization of the quality of democracy. Democratization, 23(1), 1-26.

Murzańska, A. (2011). Badania nad populizmem w Polsce. Krakowskie Studia Międzynarodowe, 4, $349-354$.

Myjak, J. S. (2020). Today's Poland as a Bastion of Conservative Populism: Targeting Families in a Populist Power Grab. Retrieved April 5, 2021, from http://www.inquiriesjournal.com/articles/1836/todayspoland-as-a-bastion-of-conservative-populism-targeting-families-in-a-populist-power-grab.

Narewska, D. (2015). Komunikacyjna dysfunkcja Definiowanie zdrowia seksualnego przez światową organizację zdrowia (WHO) i Kościół katolicki na przykładzie wybranej publicystyki. Zeszyty PRASOZNAWCZE, 2(58), 491-512.

Obrycka, M., \& Dąbrowski, Sz. (2018). Pedagogika religii jako subdyscyplina nauk o edukacji - między inkluzją a ekskluzją w badaniach edukacyjnych. Karto-Teka Gdańska, 1(2), 2-17.

Olbrycht, K. (2012). Wychowanie do wartości - w centrum aksjologicznych dylematów współczesnej edukacji. Paedagogia Christiana, 1(29), 89-104.

OSCE, (2007). Toledo Guiding Principles on Teaching about Religion and Beliefs in Public Schools. Organization for Security and Co-operation in Europe (OSCE).

Osewska, E. (2012). The current situation of education and continuing professional development of RE teachers in Poland in the context of the social challenges. The Person and the Challenges, 2(2), $123-131$.

Panizza, F. (2005). Populism and the Mirror of Democracy. Verso.

Pankowski, R. (2010). The Populist Radical Right in Poland: The Patriots. UK: Routledge.

Pickel, G. (2015). Neue Entwicklungen der politischen Kultur. Politische Einstellungen im wiedervereinigten Deutschland: Neue Krisenerscheinungen oder doch alles beim Alten? In M. Kneuer (Ed.), Standortbestimmung Deutschlands: Innere Verfasstheit und internationale Verantwortung (pp. 155194). Germany: Nomos. 
Pickel, G. (2018). Religion als Ressource für Rechtspopulismus? Zwischen Wahlverwandtschaften und Fremdzuschreibungen. Zeitschrift Für Religion, Gesellschaft Und Politik, 2, 277-312. https://doi.org/ 10.1007/s41682-018-0032-Z

Pickel, G., Jaeckel, Y., \& Yendell, A. (2015). Der Deutsche Evangelische Kirchentag - Religiöses Bekenntnis, politische Veranstaltung oder einfach nur ein Event? Nomos, Germany: Eine empirische Studie zum Kirchentagsbesuch in Dresden und Hamburg.

Pilch, T. (2020). Myśl pedagogiczna i edukacja wobec anomii, bierności obywatelskiej, dysfunkcjonalności władzy i demokracji proceduralnej. In J. Madalińska-Michalak \& A. Wiłkomirska (Eds.), Pedagogika i edukacja wobec kryzysu zaufania, wspólnotowości i autonomii (pp. 153-176). Wydawnictwo Uniwersytetu Warszawskiego.

Piwnicki, G. (2017). Relacje państwo-Kościół na przełomie XX i XXI wieku. Przypadek Polski. Cywilizacja i Polityka, 15(15), 146-164.

Polish Bishops' Conference (2001b). II. Polski Synod Plenarny (1991-1999), Potrzeby i zadania nowej ewangelizacji na przełomie II i III Tysiąclecia Chrzescijaństwa. In II. Polski Synod Plenarny (19911999) (9-28). Pallottinum.

Polish Bishops' Conference (2001a). Dyrektorium Katechetyczne Kościoła Katolickiego w Polsce. Wydawnictwo WAM.

Polish Bishops' Conference (2010b). Program nauczania religii rzymskokatolickiej $w$ przedszkolach $i$ szkołach. Wydawnictwo WAM.

Polish Bishops' Conference (2010a). Podstawa programowa katechezy Kościoła katolickiego w Polsce. Wydawnictwo WAM.

Polish Bishops' Conference (2017). Chrześcijański kształt patriotyzmu. Rada ds. Społecznych.

Polish Bishops' Conference (2018). Podstawa programowa katechezy Kościoła katolickiego w Polsce. Edycja św. Pawła.

Polish Bishops' Conference (2019). Program nauczania religii rzymskokatolickiej $w$ przedszkolach $i$ szkołach. Edycja św. Pawła.

Pontifical Council for Promoting the New Evangelization, (2020). Directory for Catechesis. Catholic Truth Society.

Przyłęcki, P. (2012b). Populizm w polskiej polityce. Analiza dyskursu polityki. Wydawnictwo Sejmowe.

Przyłęcki, P. (2012a). Populizm w polskiej polityce. Analiza dyskursu polityki. Wydawnictwo Sejmowe.

Rebenstorf, H. (2018). „Rechte“ Christen? - Empirische Analysen zur Affinität christlich-religiöser und rechtspopulistischer Positionen. Zeitschrift Für Religion, Gesellschaft Und Politik, 2(2), 313-333. https://doi.org/10.1007/s41682-018-0024-z

Roberts, K. M. (2006). Populism, political conflict, and grass-roots organization in Latin America. Comparative Politics, 38(2), 127-148.

Roy, O. (2016). Beyond populism: The conservative right, the courts, the churches and the concept of a Christian Europe. In N. Marzouki, D. McDonnell, \& O. Roy (Eds.), Saving the People: How Populists Hijack Religion (pp. 185-202). C. Hurst \& Co Publishers.

Schwendemann, W. (2016). Kompetencja religijna i religijno-pedagogiczna. Studia z Teorii Wychowania, 7(4), 79-91.

Schwörer, J. (2018). Right-wing populist parties as defender of Christianity? The case of the Italian Northern League. Zeitschrift Für Religion, Gesellschaft Und Politik, 2, 387-413.

Sołtys, A. (2015). Polityczna ideologizacja religii zagrożeniem bezpieczeństwa państw w obszarze basenu morza śródziemnego. Teka Komisji Politologii i Stosunków Międzynarodowych, 10(2), 39-52.

Spencer, N. (2017). The rise of Christian populism. Retrieved March 14, 2021, from https://www.biblesocie ty.org.uk/latest/news/the-rise-of-christian-populism/.

Stankov, N., Živković, S. (2019). The effect of religiosity: Comparison of voting for radical right-wing parties in Western and Eastern Europe. Retrieved March 9, 2021, from https://pds.ceu.edu/sites/pds.ceu. hu/files/attachment/article/1203/stankovnemanjadspsadc2019paper.pdf.

Stanley, B. (2016). Defenders of the cross: populist politics and religion in post-communist Poland. In N. Marzouki, D. McDonnell, \& O. Roy (Eds.), Saving the People: How Populists Hijack Religion (pp. 109-128). UK: C. Hurst \& Co Publishers.

Stanley, B., \& Cześnik, M. (2019). Populism in Poland. In D. Stockemer (Ed.), Populism Around the World: A Comparative Perspective (pp. 67-87). Springer.

Steinmetz-Jenkins, D., Jäger, A. (2019). The populist right is forging an unholy alliance with religion. Retrieved March 8, 2020, from https://www.theguardian.com/commentisfree/2019/jun/11/populistsright-unholy-alliance-religion.

Stępińska, A., Lipiński, A. (2020). Badania nad dyskursem populistycznym: wybrane podejścia. Wydawnictwo Naukowe Wydziału Nauk Politycznych i Dziennikarstwa. 
Stępińska, A., Lipiński, A., Hess, A., \& Piontek, D. (2017). Poland. A fourth wave of populism? In T. Aalberg, F. Esser, C. Reinemann, J. Strömbäck, \& C. H. de Vreese (Eds.), Populist political communication in Europe (pp. 311-325). UK: Routledge.

Świątek, J. (2008). Demokracja w nauczaniu papieży. Człowiek w Kulturze, 20, 85-100.

Szacki, J. (2006). Populizm a demokracja. In M. Marczewska-Rytko, Populizm na przełomie XX $i$ XXI wieku: panaceum czy pułapka wspótczesnych społeczeństw? (203-238). Wydawnictwo Adam Marszałek.

Timbro, (2019). Authoritarian Populism Index. Retrieved September 10, 2021, from https://populismindex. com/wp-content/uploads/2019/02/TAP2019C.pdf.

Tomasik, P. (2000). Ksztattowanie postaw społecznych na lekcjach religii. Retrieved March 27, 2021, from https://opoka.org.pl/biblioteka/T/TA/TAK/0009V_02.html - 20.01.2020

Tomasik, P. (2010). Nauczanie religii katolickiej w strukturze polskiej szkoły. Studia Katechetyczne, 7 , 126-148.

Tomasik, P. (2019). Wychowanie patriotyczne wyzwaniem dla katechezy Kościoła w Polsce. Colloquia Theologica Ottoniana, 2, 101-120.

Topidi, K. (2019). Religious freedom, national identity, and the polish catholic church: Converging visions of nation and god. Religions. https://doi.org/10.3390/rel10050293

Turska-Kawa, A., \& Wojtasik, W. (2020). The importance of religiosity in the formation of populist attitudes: The case of Poland. Journal for the Study of Religions and Ideologies, 19(55), 34-52.

Tworzecki, H., Markowski, R. (2017). Why is Poland's Law and Justice Party trying to rein in the judiciary? Washington Post. Retrieved January 14, 2021, from https://www.washingtonpost.com/news/ monkey-cage/wp/2017/07/26/why-is-polands-law-and-justice-party-trying-to-rein-in-the-judiciary/.

Tworzecki, H. (2019). Poland: A case of top-down polarization. Annals of the American Academy of Political and Social Science, 681, 97-119.

Tyrała, M. (2020a). Wpływ populizmu na funkcjonowanie demokracji w Polsce na przykładzie partii PiS w latach 2015-2018. In J. Jaskiernia \& K. Spryszak (Eds.), Polski system ochrony praw człowieka w dobie kryzysu demokracji liberalnej (pp. 13-24). Wydawnictwo Adam Marszałek.

Tyrała, M. (2020b). Wpływ kultury politycznej na proces funkcjonowania demokracji w Polsce w latach. Środkowoeuropejskie Studia Polityczne, 1, 97-113.

Vasileiou, A. (2021). "Rainbow Plague”: A 'New Threat' to Polish Society and EU Cohesion. Retrieved September 11, 2021, from http://edutrip.eu/files/policybriefs/Rainbow_Plague_avasileiou.pdf $-10.09 .2021$

Verkuten, M. (2014). Identity and Cultural Diversity: What Social Psychology Can Teach Us. UK: Routledge.

Wagenvoorde, R. (2019). The Religious Dimensions of Contemporary European Populism. In B. Schewel \& E. K. Wilson (Eds.), Religion and European Society: A Primer (pp. 11-123). Wiley.

Westphal, M. (2020). Populismus in der politischen Theorie. In I. C. Panreck (Ed.), Populismus - Staat Demokratie. Staat - Souveränität - Nation (pp. 157-175). NJ: Springer.

Whitehead, L. (2002). Democratization. Oxford University Press.

Woods, D., \& Wejnert, B. (2014). The many faces of populism: Current perspectives. Research in Political Sociology, 22, iii. https://doi.org/10.1108/S0895-993520140000022014

Ysseldijk, R., Matheson, K., \& Anisman, H. (2010). Religiosity as identity: Toward an understanding of religion from a social identity perspective. Personality and Social Psychology Review, 14(1), 60-71.

Zellma, A. (2003). Wychowanie patriotyczne współczesnej młodzieży polskiej w szkolnym nauczaniu religii. Studia Warmińskie, 40, 183-197.

Zembylas, M., \& Loukaidis, L. (2016). Emerging relationships between religious education and citizenship education: Teachers' perceptions and political dilemmas in Cyprus. British Journal of Religious Education. https://doi.org/10.1080/01416200.2016.1209459

Zybała, A. (2019). Edukacja moralna w oświacie - trendy i bariery. Studia z Polityki Publicznej, 4(24), $81-98$.

Publisher's Note Springer Nature remains neutral with regard to jurisdictional claims in published maps and institutional affiliations. 